УДК 821.112.2.09

DOI https://doi.org/10.24919/2308-4863/34-4-18

\author{
Тетяна РЕДЧИЦЬ, \\ orcid.org/0000-0003-3497-7699 \\ кандидат філологічних наук, \\ доиент кафедри прикладної лінгвістики та перекладу \\ Черкаського державного технологічного університету \\ (Черкаси, Україна) tania_redchyts@ukr.net
}

\title{
АМЕРИКА В ЖИТТІ І ТВОРЧОСТІ БЕРТОЛЬДА БРЕХТА
}

\begin{abstract}
У науковому викладі здійснено спробу докладно розглянути проблему «Америка в житті й творчості Б. Брехта», зосередивши першочергову увагу на художніх функиіях образу Америки в п'єсах і поетичних творах німецького драматурга-новатора. Насамперед зазначимо, щзо уявлення Бертольда Брехта про Америку, так само як $i$ розуміння того, яке місие вони займали в картині світу мития, можуть бути реконструйовані на підставі тих розрізнених вербальних репрезентацій, які зустрічаються в його листах, щоденникових записах, віршах, драматичних творах. Спочатку американський «колорит» у творах Брехта забезпечувався використанням відомостей про типові прикмети американського стилю життя, джерелом яких були романи американських авторів, фільми, а також та інформація, щзо доходила з-за океану. Згодом до иъього додалися власні враження від американської дійсності. Під час аналізу проблеми «Брехт та Америка» вихідним положенням став висновок Р. Брюстайна про те, щуо уявлення Б. Брехта про Америку (внаслідок колізій його життя) змінювалося щонайменше двічі; отже, у своєму житті драматург «пізнав», принаймні, дві різних Америки. Образ периої з них - далекий від реальності, сповнений романтичних ілюзій та екзотики Дикого Заходу - формується у свідомості майбутнього метра ще в ранній юності. Формування нового ставлення до Америки й, відповідно, нового ї бачення відбувається, коли Б. Брехт на власному досвіді пізнає реалії життя в країні. Характерними відмінностями драматичних творів иьвого часу є умисна американізація, колоквіалізація та «джазування» мови й манер. Важливим компонентом уявлень Брехта про Америку є передусім БАГАТСТВО. Ця складова частина образу Америки реалізується 6 поемах через одинииі лексико-семантичних полів ЗОЛОТО й НАФТА. Сутність сприйняття німецьким митцем американської ичивілізації визначають ідеї ПРОДАЖНОСТІ й суичільної КОМЕРЦІАЛІЗАЦІЇ мистецтвва. Важливе місие в структурі уявлень Брехта (як драматурга- й режисера-новатора) про Америку посідає така складова частина, як КІНОІНДУСТРІЯ. Розглянутий текстовий матеріал засвідчує, щзо семилітнє перебування Брехта в США, занурення в американську дійсність повністю змінило уявлення мития про крайну його юнацьких мрій, відповідним чином змінивши й художні функиії образу Америки. На зміну уявно міфологізованому хронотопу його n'єс приходить справжня реальність, яка диктує інші художні засоби відбиття американської дійсності.
\end{abstract}

Ключові слова: Бертольд Брехт, Америка, локус, американізація, колоквіалізація та «джазування» мови.

Tetiana REDCHYTS, orcid.org/0000-0003-3497-7699

Candidate of Philological Sciences, Associate Professor at the Department of Applied Linguistics and Translation Cherkasy State Technologikal University (Cherkasy,Ukraine) tania_redchyts@ukr.net

\section{AMERICA IN THE LIFE AND CREATIVE WORK OF BRECHT}

This scholarly presentation attempts to examine in detail the problem of "America in the life and creative work of Brecht", focusing primarily on the artistic functions of the image of America in the plays of the German playwrightinnovator. First, we will mention, that Berthold Brecht's ideas about America - as well as an understanding of what place they occupied in the picture of the artist's world, can be reconstructed based on those disparate verbal representations, which are found in his letters, diaries, poems, plays. Initially, the American "color" in Brecht's works was provided by the use of information about the typical features of the American lifestyle, the source of which were American authors' novels, films, and information that was coming from overseas. Later, he added his impressions of American reality. In analyzing the problem of "Brecht and America", the starting point was the conclusion of R. Brustein that Brecht's ideas of America (due to the collisions of his life) changed at least twice; therefore, in his life, the playwright "learned" at least two different Americas. The image of the first of them is far from reality, full of romantic illusions and exotics of the Wild West - formed in the minds of the future maitre in early adolescence. The formation of a new attitude towards America and, respectively, a new vision of it, occurs when Brecht learns from his own experience the realities of life in this country. Characteristic differences of dramatic works of this time are intentional Americanization, colloquialization, and "jazzing" of language and manners. WEALTH is an important component of Brecht's ideas about America. This 
component of the image of America is realized in the poem through the units of lexical and semantic fields GOLD and OIL. The essence of the German artist's perception of American civilization is determined by the ideas of SALES and continuous COMMERCIALIZATION of art. An important place in the structure of Brecht's ideas (as a playwright and film director-innovator) about America is occupied by such a component as the CINEMA INDUSTRY. The considered text material testifies that Brecht's seven-year stay in the USA, immersion in American reality completely changed the artist's perception of the country of his youthful dreams, appropriately changed the artistic functions of the image of America. The imaginary mythologized chronotope of his plays is replaced by real reality, which dictates other artistic means of reflecting American reality.

Key words: Berthold Brecht, America, locus, intentional Americanization, colloquialization, and "jazzing" of language.

Постановка проблеми. Бертольд Брехт належить до числа найбільш знакових постатей у літературі XX століття. Його концепція «епічного театру» вплинула на театр практично всіх країн заходу, визначивши театральне обличчя XX століття: вже в 1950-х роках п'єси Брехта твердо увійшли в театральний репертуар; його ідеї тією чи іншою формою були сприйняті багатьма драматургами-сучасниками й наступниками, серед яких Фрідріх Дюрренматт, Артюр Адамов, Макс Фріш, Хайнер Мюллер, Джон Арден, Едвард Бонд та інші.

$€$ С. Д. Сурков зазначив із цього природу, що теорія «епічного театру», втілена в практику Брехтомрежисером у післявоєнні роки, відкрила принципово нові можливості сценічного мистецтва й мала значний вплив на розвиток театру XX століття (Сурков, 1965: 5, 13). Німецька дослідниця історії театру Маріанна Кестінг наголошує, що «якщо нині більшість живих авторів «хворі Брехтом» ("brechtkrank"), то це пояснюється тим, що його позиція досі не могла бути подолана будьякою іншою, настільки ж значною та внутрішньо цілісною концепцією» (Kesting1962: 69-70).

Цілком зрозуміло, що за життя письменника, коли його новаторська концепція «епічного театру» здобула широке визнання, та впродовж десятиліть, що минули від смерті письменника, його життєвий шлях, естетичні принципи й художні доробки докладно розглядалися науковцями різних країн передусім у площині його новаторських художніх відкриттів.

Аналіз досліджень. Доробок Б. Брехта не раз ставав об' єктом пильної уваги як зарубіжних, так i вітчизняних германістів. Предметом дослідження в праці українського літературознавця О. С. Чиркова «Бертольт Брехт. Про мистецтво театру» стали теоретичні погляди видатного німецького драматурга. А в 1988 році вийшла у світ монографія докторської роботи О. С. Чиркова, присвячена епічній драмі. Проблема ефекту очуження як теоретико-літературна категорія розглядається в науковій розвідці С. Ф. Соколовської. Різні аспекти творчості німецького драматурга викладені в працях Н. В Возненко, Н. І. Астрахан, В. О. Гриневича, В. В. Грицюка, І. П. Бабія, І. М. Фрадкіна.
Творчість Брехта грунтовніше й різнобічніше вивчалася переважно на Заході (Й. Екхарт, В. Міттенцвай, М. Прілль). Інтертекстуальності у твоpax німецького драматурга присвячені наукові розвідки зарубіжних германістів М. Боймера й М. Гаккарайнена.

Отже, поза зоною уваги фахівців залишилися деякі аспектитворчостімитця, зокрематі,щодозволяють розглядати його театральні доробки в перспективі загальних тенденцій розвитку літератури й стосуються питань жанрології, часопросторової організації тощо. 3' ясування цих питань дозволить заповнити наявні натепер у брехтознавстві лакуни й створити ціліснішу картину творчості митця.

Одна 3 таких лакун стосується теми Америки в житті й творчості Б. Брехта, яка натепер не отримала свого належного - системного-викладеннявлітературознавстві аніЗахідної, ані Східної Європи. Єдиний виняток у цьому відношенні становлять англомовні розвідки таких сучасних американських дослідників, як Robert Brustein (Brustein, 1981), James K. Lyon (Lyon, 1992), Patty L. Parmalee (вперше опубл.: Irvine: University of California, 1970). Однак вони сфокусовані здебільшого на біографічних аспектах проблеми, тоді як її поетологічні виміри практично не розглядаються.

Мета статті полягає у встановленні особливостей уявлень Б. Брехта (як драматурга й режисера-новатора) про Америку й у визначенні характерних відмінностей драматичних і поетичних творів часів американської еміграції.

Виклад основного матеріалу. У своєму науковому викладі ми спробували докладніше розглянути проблему «Америка в житті й творчості Б. Брехта», зосередивши першочергову увагу на художніх функціях образу Америки в п'єсах німецького драматурга-новатора. Насамперед зазначимо, що уявлення Б. Брехта про Америку, - так само як і розуміння того, яке місце вони займали в картині світу митця, - можуть бути реконструйовані на підставі тих розрізнених вербальних репрезентацій, які зустрічаються в його листах, щоденникових записах, віршах, драматичних творах. 
Під час аналізу проблеми «Брехт та Америка» вихідним положенням став висновок Р. Брюстайна про те, що уявлення Б. Брехта про Америку (внаслідок колізій його життя) змінювалося щонайменше двічі; отже, як твердить критик, у своєму житті драматург пізнав, принаймні, дві різних Америки (Brustein, 1981).

Образ першої з них - далекий від реальності, сповнений романтичних ілюзій та екзотики Дикого Заходу - формується у свідомості майбутнього метра ще в ранній юності. Так, 1916 року він пише у своєму щоденнику: «Я можу писати, можу складати п'єси краще за Геббеля чи Ведекінда. Але я ледачий. Знаменитим не стану. А якщо стану - вирушу в Америку, наймуся ковбоєм: увесь день в сідлі, дивлюся на небо, розмовляю з биками ŭ підслуховую, як росте трава». Однак цей щоденниковий запис свідчить і про інше: майбутній корифей європейського театру добре усвідомлював, що «без імені» в країні його мрій робити нічого.

Однак образ Америки продовжував хвилювати його уяву. Захоплення Брехта Америкою тривало й у 1920-х роках: як і багато інших європейців, він був зачарований американською попкультурою, яка культивувалася засобами масової інформації. У його уяві далека Америка поставала як країна, де було подолано вбогість і посередність, країна непередбачувана й екстравагантна, країна великих міст і ділків великого бізнесу. Цей образ так дисонував із вбогою, непривабливою дійсністю післявоєнної Німеччини, з їі всюдисущими дрібними спекулянтами й «млявою» «поміркованістю» іiі жителів. Образ батьківщини, що втратила історичний оптимізм, молодий Брехт створює в одному з віршів 1919 року, протиставляючи їй саме Америку:

O Aasland, Kummernisloch!

Und in den Jungen, die du

Nicht verdorben hast

Erwacht Amerika!

(цит. за: Hoover, 1975: 285).

Аналогічні думки зустрічаються й у щоденнику Брехта. Так, 18 червня 1920 року молодий поет записав: «Яку нудьгу наводить на мене Німеччина. < .. > Що ж залишається? Америка!» (цит. за: Fetscher, 1970: 246).

Захоплення Брехта Америкою визначає присутність «американської» теми в п’єсах митця 1920-30-х років, таких як «У нетрях міст» ("Im Dickicht der Städte", 1924 рік), «Махагоні» ("Mahagonny Songspiel”, 1927 рік), «Свята Іоанна скотобоєн» ("Die heilige Johanna der Schlachthofe", 1927 рік), «Зліт і падіння міста Махагоні» (“Aufstieg und Fall der Stadt Mahagonny”, 1931 рік).
Завершує цей ряд п’єса «Сходженню Артуро Уї можна було завадити» ("Der aufhaltsame Aufstieg des Arturo Ui”), задумана Брехтом ще 1935 року під час його першого візиту до США під впливом вражень від американської дійсності.

Характерними відмінностями цих драматичних творів $\epsilon$, на думку американської дослідниці Елеонор Хакім, умисна американізація, колоквіалізація та «джазування» мови й манер, що особливо помітні у творі «Кар'єра Артуро Уї, яку можна було спинити» (Hakim, 1965: 21).

Ця «умисна» американізація проявляється насамперед через вибір місия діi. У більшості «американських» драматургічних доробків Брехта - таких як «У нетрях міст», «Свята Іоанна скотобоєн», «Кар'єра Артуро Уї, яку можна було спинити» - місцем дії виступає Чикаго, на той час друге за кількістю населення місто США, великий індустріальний центр, Мекка емігрантів. На ранньому етапі творчості вибір саме Чикаго як місця дії «американських» п’єс був зумовлений впливом на Брехта роману Е. Синклера "The Jungle" (1906 рік). У 1920-х роках місто здобуло міжнародної «слави» через стрімке зростання рівня організованої злочинності.

Зазначимо, що, як уже спостерегли американські дослідники, в Брехта спочатку було дуже непевне уявлення про географію США - в одній п’єсі Чикаго є портом південних морів, в іншій знаходиться на відстані чотирнадцяти днів шляху від озера Мічиган. Така неточність географічних координат, схематизм прикмет міського життя США (бокс, гангстери й таке інше) забезпечили умовність спатіальних характеристик названих творів. Внаслідок цього їх часопростір набуває умовно-алегоричного характеру, а подекуди відверто міфологізується, дистанціюючи події, описані у творах, від реального часу й простору, в якому локалізований сам автор.

Такий спосіб художньо-просторової організації Б. Брехтом його п’єс забезпечує їх «соціологізм, інтелектуалізм, втілення актуальних проблем у параболічній формі й зумовлене параболічною побудовою алегоричне, притчове, а також парадоксальне, гротескове й сатиричне осмислення соціальної дійсності» (Свченко, 2004: 166). Водночас домінантною - на противагу твердженню М. М. Бахтіна щодо часу як «провідного початку в хронотопі» (Бахтин, 1986: 122) - виступає геопросторова координата, МІСЦЕ й пов'язані з ним культурні смисли.

Таким чином, у п'єсах Брехта (не лише «американських») «основне сюжетоутворювальне значення», про яке писав М. М. Бахтін (Бахтин, 
1986: 282), переходить до «місця», а твори набирають жанрових ознак n'єси-антиутопї - таких, зокрема, як «критичне ставлення до соціуму, мотив передбачення майбутнього, що супроводжується бідами, хворобами, катастрофами, війнами» (Свечникова, 2012: 125).

3 максимальною чіткістю «другий», якісно цілком відмінний образ Америки, формується у свідомості Брехта, коли він, змушений після приходу до влади в Німеччині нацистів залишити батьківщину, проводить у Штатах шість із чотирнадцяти років вигнання (1941-1947 роки).

Брехт прибув до гавані Лос-Анджелеса в СанПедро 21 липня 1941 року. Переїжджаючи до Америки, Б. Брехт, як зазначає німецький дослідник Крістіан Бонерт, сподівався покінчити з ізоляцією (якої він зазнав у Скандинавії та Фінляндії після вимушеного від'їзду з нацистської Німеччини), сподівався знову розпочати практичну роботу. Він вбачав в Америці одну з небагатьох країн, де можна вільно займатися літературою (Bohnert, 1982: 162f). Однак після свого приїзду до Каліфорнії 1941 року Брехт, як зазначає К. Бонерт, пережив справжній шок. Чи не найголовнішим випробуванням, а отже, й чинником його нелюбові до США стала відсутність фінансового успіху. Як неодноразово наголошували біографи Брехта, в Каліфорнії він був змушений жити із щомісячних виплат, передбачених Європейським фондом кіно (Bohnert, 1982: 162f). Усі ці драматичні колізії часів американської еміграції Брехта дуже містко виразилися й у його поетичних доробках, зокрема в «Сонеті еміграції» (“Sonett der Emigration”) (1941):

$<\ldots>$ Verjagt aus meinem Land muss ich nun sehn

Wie ich zu einem neuen Laden komme, einer Schenke

Wo ich verkaufen kann das, was ich denke

Die alten Wege muss ich wieder gehen.

Die glatt geschliffenen durch den Tritt der Hoffnungslosen!

Schon gehend, weiß ich noch nicht: zu wem?

Wohin ich komme, hör ich: Spell your name!

Ach, dieser 'name' gehörte zu den großen!

(https://fluchtingedichten.wordpress.com/viertesgedicht).

Суттєвий дискомфорт для Брехта створювала віддаленість від «його» аудиторії, мовний бар'єр, а також та обставина, що він і його творчість були не досить відомими в Америці. Це спричиняло ту «надзвичайну інтелектуальну ізоляцію», на яку нарікав Брехт у своїх листах. У порівнянні з тим, як письменник почувався в Голлівуді, маленький Свендборг на усамітненому острівці в Данії був, за словами драматурга, світовим центром.
Культурний шок в часі семилітнього перебування Брехта в США спричинили й особливості каліфорнійських краєвидів і клімату, а також прагматизм і меркантильність американської цивілізації, де, як наголошував драматург, кожен завжди щось купував і продавав. Такі умови життя були абсолютно чужорідними для нього. Це усвідомлення омріяної колись Америки як абсолютно чужсого простору пронизує його щоденники, листи й лірику «каліфорнійського» періоду. Так, Брехт нарікав, що в каліфорнійському кліматі йому нічим дихати, бо повітря геть позбавлене запахів, однакове вранці й ввечері, в будинку й в саду. Деталі ландшафту, які міг розрізнити письменник, їдучи на авто в Беверлі-Гіллс, назагал цілком привабливі, виглядали немов би за вітринним склом, а очі на кожному ланцюжку пагорбів, на кожному лимонному деревці мимоволі шукали маленький цінник. Такі цінники шукав письменник тут і на людях.

У своїх щоденниках і спогадах - як відмінної прикмети американської культури й свідомості - письменник виокремлює штучно створювану «дешеву привабливість». Уже повернувшись 1948 року до Європи, Брехт, порівнюючи іiі ландшафт і барви з Америкою, напише у своєму щоденнику: «Перша весна в Свропі за останні вісім років. Фарби рослинного світу набагато свіжіші й ніжніші, аніж каліфорнійські. Планування не розраховане 3 математичною точністю, як в декоративних садах і на плантаціях Каліфорнії».

Виставна привабливість, НЕприродність (=НЕсправжність) та облуда, готовність ошукати й продати усіх й уся (або продатися заради власної вигоди) як визначальні риси «другої» не уявної, а реальної - Америки, яку він спізнав, лише занурившись в американську дійсність, на повну силу розкриваються в його невеликій поемі "Hollywoodelegien" (1942 рік). Нове бачення країни своїх юнацьких мрій Брехт передає через низку аксіологічно забарвлених алегоричнометафоричних образів. Америка бачиться йому як величезне торговище, на якому продаються обмани (“Markt, wo Lügen gekauft werden”). Цей образ проєктується і на американське суспільство в цілому, й на окремі його грані, в тому числі й кіноіндустрію та Голлівуд, який продукує і продає обмани ("Ihre Söhne / Haben die Traumfabriken von Hollywood gebaut").

Біблійно-міфологічне трактування «верху» й «низу» поєднується в елегії Брехта із соціальним звучанням:

Über den vier Städten kreisen die Jagdflieger

Der Verteidigung. In großer Höhe 
Damit der Gestank der Gier und des Elends

Nicht bis zu ihnen heraufdringt.

(Brecht, 1964: 115f).

У своїй «Голлівудській елегії» Брехт окреслює кілька ключових складових частин образу Америки. Актуалізуючи семантику назви Лос-Анджелес («місто ангелів»), він інтерпретує її в біблійноміфологічному контексті - як простір, що $є$ водночас ВЕРХОМ і НИЗОМ, РАСМ і ПЕКЛОМ:

Das Dorf Hollywood ist entworfen nach den Vorstellungen

Die man hierorts vom Himmel hat. Hierorts

Hat man ausgerechnet, daß Gott

HIMMEL und HÖLLE benötigend, nicht zwei

Etablissements zu entwerfen brauchte, sondern

Nur ein einziges, nämlich den Himmel. Dieser

Dient für die Unbemittelten, Erfolglosen

Als Hölle.

(Brecht, 1964: 115f).

Важливим компонентом уявлень Брехта про Америку $є$ передусім БАГАТСТВО. Ця складова частина образу Америки реалізується в поемі через одиниці лексико-семантичних полів ЗОЛОТО (Goldwäscher, goldene Pessare) та НАФТА (Öltürme, Ölgeruch, riechen nach Öl). Деякі із цих лексичних презентацій мають яскравий метафоричний характер, наприклад, Ölgeruch, що одночасно сприймається як запах нафти та як запах великих грошей.

Сутність сприйняття німецьким митцем американської цивілізації визначають ідеї ПРОДАЖНОСТІ й суцільної КОМЕРЦІАЛІЗАЦІЇ мистецтва. Письменники й музиканти, Данте й Бах виходять немов би на панель, пропонуючи купити свій талант:

Gehen die Musiker auf den Strich, zwei und zwei

Mit den Schreibern. Bach

Hat ein Streichquartett im Täschchen. Dante schwenkt

Den dürren Hintern

(Brecht, 1964: 115f).

«Ангели», від яких тхне нафтою та великими грошима, підгодовують продажну пресу ("Füttern sie allmorgendlich die Schreiber in ihren Schwimmpfühlen").

Важливе місце в структурі уявлень Брехта (як драматурга й режисера-новатора) про Америку посідає така складова частина, як КІНОІНДУСТРІЯ, особливо якщо взяти до уваги, що сім років митець жив територіально близько до Голлівуду, відомої на увесь світ «фабрики мрій».
Для Брехта як митця, котрий намагався своїми п'єсами пробудити думку аудиторії, примусити iii замислитися над причинами зображуваних у тому чи іншому творі подій, неприйнятними були оманливі «мрії про щастя», які тиражували в Голлівуді, записуючи на кіноплівку ("Die man hier auf Zelluloid schreibt"). Зрештою, вся Америка мислиться Брехтом як "Das Dorf Hollywood", де за гарненьким фасадом 3 ілюзій і мрій криється неприваблива й жахлива дійсність.

Узяті назагал, уявлення Брехта про Америку,продиктовані колізіями життя митця та відбиті у його творчості, складаються в певний образ, що становить синтетичне утворення, яке конструюється 3 фрагментів фільмів, романів, заголовків новин.

На початках американський «колорит» у твоpax Брехта забезпечувався використанням відомостей про типові прикмети американського стилю життя, джерелом яких були романи американських авторів, фільми, а також та інформація, що доходила з-за океану й розносилася тодішніми німецькими мас-медіа. Згодом до цього додалися власні враження від американської дійсності.

Отже, Америка в літературних доробках Б. Брехта репрезентується завдяки використанню:

1) урбанонімів - назв міст і населених пунктів (Чикаго, Нью-Йорк, Санта-Моніка, Беверлі-Хілз, Лос-Анджелес, Голлівуд), а також узагальнених номінацій (міста-гіганти);

2) назв окремих штатів США й країни в цілому (Каліфорнія тощо);

3) назв найвідоміших американських вулиць, що є символами Америки (Волл-Стріт, Бродвей);

5) назв ландшафтних реалій Америки, «чужих» для європейця (наприклад, прерія чи плантачія);

6) назв певних соціальних типів, не властивих Європі (гангстер);

7) назв економічно-промислових об'єднань (корпорачія);

8) використання англійських слів і фраз і таке інше.

Висновки. Підсумовуючи зазначене, можемо констатувати, що розглянутий вище текстовий матеріал засвідчує, що шестилітнє перебування Б. Брехта в США, занурення в американську дійсність повністю змінило уявлення митця про країну його юнацьких мрій, відповідним чином змінивши й художні функції образу Америки. На зміну уявно міфологізованому хронотопу його п’єс приходить справжня реальність, яка диктує інші художні засоби зображення американської дійсності. 


\section{СПИСОК ВИКОРИСТАНИХ ДЖЕРЕЛ}

1. Бахтин М. М. Формы времени и хронотопа в романе. Очерки исторической поэтики. Литературно-критические статьи / М. М. Бахтин. Москва : Худож. лит. 1986. С. 121-190.

2. Свченко О. В. Деякі родові риси поетики драми-антиутопії. Вісн. Житомир. держ. ун-ту. 2004. № 15. С. $166-170$.

3. Свечникова Е. В. Черты массовой культуры в белорусской антиутопии. Вестник Полоцкого государственного университета. Серия Е: Педагогические науки. Культурология. 2012. С. 125-128.

4. Сурков Е.Д. Путь к Брехту. Театр: Пьесы. Статьи. Высказывания : в 5 т. / Б. Брехт. Москва : Искусство, 1965. T. 5. C. 5-58.

5. Bohnert C. Brechts Lyrik im Kontext: Zyklen und Exil. Königstein/Ts. : Athenäum, 1982. $320 \mathrm{~S}$.

6. Brecht B. Hollywoodelegien. Werke, Gesamtausgabe. Bd. 12. / B. Brecht. Frankfurt am Main : Suhrkamp Verlag, 1964. S. 115.

7. Brecht B. Sonett der Emigration. URL: https://fluchtingedichten.wordpress.com/ viertes-gedicht/ (дата звернення: 20.09.2020).

8. Brustein R. Brecht in Asphalt. The New York Review of Books. 1981. February, 5. URL: http://www.nybooks.com/ articles/archives/1981/feb/ 05/brecht-in-asphalt/ (дата звернення: 22.09.2020).

9. Fetscher I. Bertold Brecht and America. Salmagundi. No. 10/11. Fall 1969-Winter 1970. P. 246-272.

10. Hakim E. St. Brecht Of The Theatrical Stock Exchange. Review. 1965. No. 1. P. 15-37.

11. Hoover M. L. "Ihr geht gemeinsam den Weg nach unten,, / Aufstieg und Fall Amerikas im Werk Bertold Brecht? Amerika in der deutschen Literatur. Neue Welt - Nordamerika - USA, Stuttgart, 1975. S. 294-314.

12. Kesting M. Panorama des zeitgenössischen Theaters. München : R. Piper-Verlag, 1962. 264 S.

13. Lyon J. K. Berthold Brecht in America. Princeton University Press, 1992. 408 p.

14. Parmalee P. L. Brecht's America. Ohio State University Press. 350 p.

15. Raithel T. „Amerika“ als Herausforderung in Deutschland und Frankreich in den 1920er Jahren. Deutschland Frankreich - Nordamerika: Transfers, Imaginationen, Beziehungen. Schriftenreihe des Deutsch-Französischen Historikerkomitees / Chantal Metzger, Hartmut Kaelble. Frankfurt : Franz Steiner Verlag, 2006. S. 82-97.

\section{REFERENCES}

1. Bakhtin M. M. Formy vremeni i khronotopa v romane [Forms of time and chronotope in the novel]. Ocherki istoricheskoi poetiki//Literaturno-kriticheskie stati. M.: Khudozh. lit. 1986. S. 121-190. [in Russian].

2. Jevchenko O. V. Deyaki rodovi rysy poetyky dramy-antyutopii [Some generic features of the poetics of anti-utopian drama]. Visn. Zhytomyr. derzh. un-tu. 2004. № 15. S. 166-170. [in Ukrainian].

3. Svechnikova E. B. Cherty massovoi kultury v belorusskoi antiutopii [Traits of mass culture in Belarusian anti-utopia]. Vestnik Polotskogo gosudarstvennogo universiteta. Seriya E: Pedagogicheskie nauki. Kulturologiya. 2012. S. $125-128$. [in Russian].

4. Surkov E. D. Put k Brechtu [Way to Brecht]. Brecht B. Teatr: Pyesy. Statyi. Vyskazyvaniya: v 5 t. M.: Iskusstvo, 1965. T. 5. S. 5-58. [in Russian].

5. 5. Bohnert C. Brechts Lyrik im Kontext: Zyklen und Exil. Königstein /Ts. : Athenäum, 1982. $320 \mathrm{~S}$.

6. Brecht B. Hollywoodelegien / Brecht B. Werke, Gesamtausgabe. Bd. 12. Frankfurt am Main: Suhrkamp Verlag, 1964. S. 115.

7. Brecht B. Sonett der Emigration; URL: https://fluchtingedichten.wordpress.com/ viertes-gedicht/.

8. Brustein R. Brecht in Asphalt / The New York Review of Books. 1981. February, 5; URL: http://www.nybooks.com/ articles/archives/1981/feb/05/brecht-in-asphalt/.

9. Fetscher I. Bertold Brecht and America / Salmagundi. No. 10/11, Fall 1969-Winter 1970. Pp. $246-272$.

10. Hakim E. St. Brecht Of The Theatrical Stock Exchange. Review. 1965. No. 1. Pp. 15-37.

11. Hoover M. L. "Ihr geht gemeinsam den Weg nach unten"/ Aufstieg und Fall Amerikas im Werk Bertold Brecht? // Amerika in der deutschen Literatur. Neue Welt - Nordamerika - USA, Stuttgart, 1975. S. 294-314.

12. Kesting M. Panorama des zeitgenössischen Theaters. München: R. Piper-Verlag, 1962. 264 S.

13. Lyon J. K. Berthold Brecht in America. Princeton University Press, 1992. 408 p.

14. Parmalee P. L. Brecht's America. Ohio State University Press. 350 p.

15. Raithel T. „Amerika“ als Herausforderung in Deutschland und Frankreich in den 1920er Jahren // Chantal Metzger, Hartmut Kaelble. Deutschland - Frankreich - Nordamerika: Transfers, Imaginationen, Beziehungen. Schriftenreihe des Deutsch-Französischen Historikerkomitees. Frankfurt Franz Steiner Verlag, 2006. Pp. 82-97. 